\title{
沖縄県幼児の体格・顔面頭蓋・雬列弓の成長変化に関する研究
}

\author{
九州亩科大学口腔衛生学講座 (指導 : 佐伯榮一教授) \\ 大内英明・伊波富夫・小田耕平 \\ 宮 崎 秀夫・児島正明・井上宗子 \\ 洛 合 真 澄・三瀬 恒 雄 - 中 野 和 俊 \\ 昭和55年 4 月 9 日受付 \\ (本稿の要旨の一部は昭和54年 6 月, 第39回九州歯科学会総会で発表した)
}

\section{Growth Changes in Physique, Cranioface, and Dentition of Preschool Period Children in Okinawa}

\author{
Hideaki Oh-uchi, Tomio Iha, Kouhei Oda, \\ Hideo Miyazaki, Masaaki Kojima, Kyoko Inoue, \\ Masumi Ochiai, Tsuneo Mise and Kazutoshi Nakano \\ Department of Preventive Dentistry (Director: Prof. Eiichi Saeki) \\ Kyushu Dental College, Kitakyushu, Japan
}

\begin{abstract}
In order to investigate the relations between the morphological changes in the deciduous dentition and the changes in the cranioface and the physique, a total of 263 children of dental age II A (156 boys and 107 girls) in nursery schools in Naha, Okinawa were examined for eight items as height.
\end{abstract}

The results were as follows:

1. In comparison with the national averages, both boys and girls in Okinawa were shorter in height but did not vary significantly in weight.

2. The Rohrer Index was about the same as the national average.

3. The morphlogy of the cranioface of both boys and girls was hyperbrachycephaly and euryprosopic-mesoprosopic.

4. In the relations between the cranioface and dentition, both maxlla and mandible were relatively stable in skeletal structure, whereas the dentition width tended to decrease slightly with aging.

\section{粕言}

小児の柬科予防処置を行うには，成長発育を十分考慮 する必要がある，乳曾列の咬合状熊は，将来永久䨑列の 咬合状態に対して，大きな影響を及ぼすとされている 1-4)，さらに，成長発育に伴う些列の変化は，全身及び 顔面頭蓋との成長発育をあわせて検討することが重要で ある。
従来, 成長発育に関する研究は数多く報告されている が, 体格, 顔面頭蓋及び囪列弓の成長変化を関連づけて 考察した報告は少なくらー7〉，永久雨列の基礎ともいえる 乳宷列期の生体計測をあわせ行った報告はないようであ る.

そこで, 著者らは乳䨑列弓の形態学的変化と顔面頭 蓋, 体格の成長発育変化について検索するために, 沖縄 


\begin{tabular}{|c|c|c|c|c|}
\hline & $3 \mathrm{y}$ & $4 \mathrm{y}$ & $5 \mathrm{y}$ & 計 \\
\hline 男 性 & $\begin{array}{c}61 \\
3 y 6 m\end{array}$ & $\begin{array}{c}70 \\
4 y 6 \mathrm{~m}\end{array}$ & $\begin{array}{c}25 \\
5 \mathrm{y} 1 \mathrm{~m}\end{array}$ & 156 \\
\hline 女 性 & $\begin{array}{c}40 \\
3 y 6 m\end{array}$ & $\begin{array}{c}54 \\
4 \mathrm{y} 4 \mathrm{~m}\end{array}$ & $\begin{array}{c}13 \\
5 y 1 \mathrm{~m}\end{array}$ & 107 \\
\hline 合 計 & $\begin{array}{c}101 \\
3 y 6 \mathrm{~m}\end{array}$ & $\begin{array}{c}124 \\
4 \mathrm{y} 5 \mathrm{~m}\end{array}$ & $\begin{array}{c}38 \\
5 y 1 m\end{array}$ & 263 \\
\hline
\end{tabular}

県那草市の保育園園児について生体計測と菌列石管模型 を採得し，検討した結果，いくつかの知見を得たので報 告する.

\section{研究資料及び方法}

\section{研究資料}

沖縄県那霸市内の 6 つの保育園園児のうち, Hellman dental age II A すなわち, 乳歯列咬合が完成し, 第 1 大曰歯萌出以前の乳菌列を有する, 男子 156 名, 女子 107 名, 言广263名を対象として, 略和 52,53 年 $5 ， 6 ， 9$ 月に採得した以下の瘝料

1. 身長, 体重, 胸囲
2. 生体顔面頭蓋計測

3. 歯列石毫模型 資料の年齢, 男女構成は表 1 亿示す通りである。 研究方法

1. 体格：通法に従い, 身長, 胸囲については $\mathrm{mm}$ 単 位，体重は1/10kg単位まで計測した。

2. 生体顔面頭蓋計測：Marchin-Saller の方法に従 $\left(^{8)}\right.$ ，生体上で直接mm単位まで計測した(図 $1 ， 2$ )。

3. 歯列石高模型：アルジネート印象材にて印象採得 後，直ちに硬石育を流入し，ての模型上でノギスを用い て1/10mm単位まで計測した（図 3 ).

計測值は棄却検定 ${ }^{9}$ の後, 一下記の公式にて求めた。

$$
\begin{aligned}
& \text { 算術平均値 } \bar{X}=\frac{\Sigma X}{N} \\
& \text { 標準偏差 } \mathrm{S} \mathrm{D}=\sqrt{\frac{\Sigma \mathrm{X}^{2}-(\Sigma \bar{X})^{2} / \mathrm{N}}{\mathrm{N}-1}}
\end{aligned}
$$

\section{結果}

体 格

身長，体重，胸囲について表 2 亿示した。

5 歳の身長で女子が男子とほぼ同じ值を示した以外， すべて男子の方が大きな值を示した。

顔面頭蓋

図1，2亿示した, 最大頭長, 最大頭幅, 煩弓幅, 下

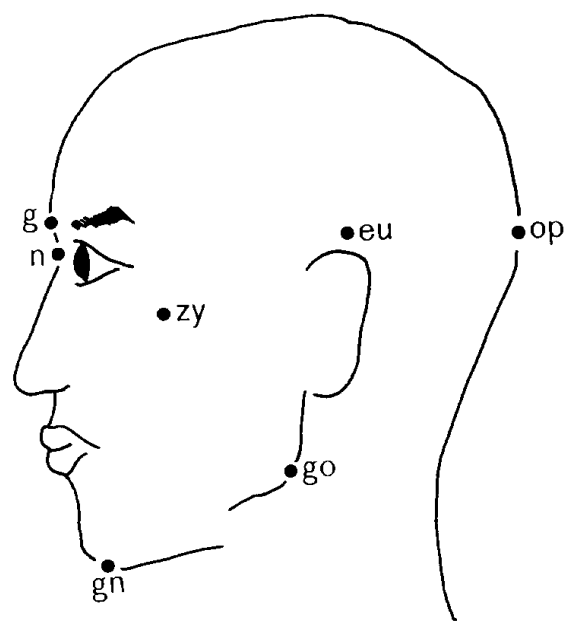

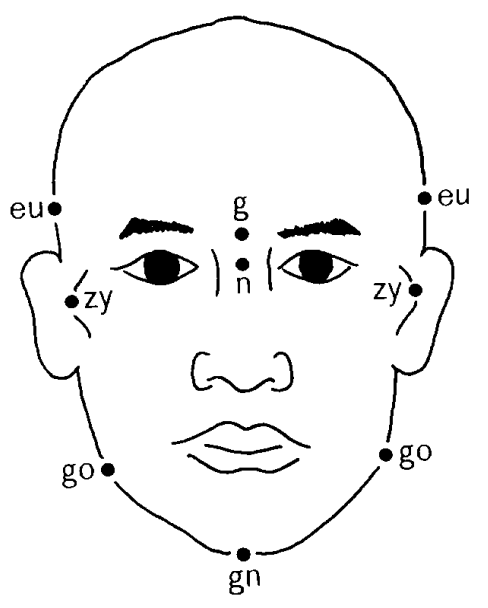

最大頭長：Glabella（g）－Opisthokranion（op）間の值線距離

最大頭幅：左右Euryon（eu）間の直線距離 煩 弓 幅：左右Zygion $(\mathrm{zy})$ 間の直線距離 下硕角幅: 左右Gonion（go）間の直線距離 形態学顔高：Nasion $(\mathrm{n})$ - Gnathion (gn) 閻の直線距離

図 1 生体 頭 部 計測 点 


\begin{tabular}{|c|c|c|c|c|}
\hline \multirow[b]{2}{*}{ 男 } & & 身長（cm) & 体重（kg) & 胸国 $(\mathrm{cm}$ \\
\hline & $3 y$ & $95.9 \pm 3.6$ & $14.9 \pm 1.4$ & $52.8 \pm 1.6$ \\
\hline \multirow[b]{2}{*}{ 性 } & $4 \mathrm{y}$ & $100 \cdot 6 \pm 4.3$ & $16 \cdot 0 \pm 1 \cdot 7$ & $53.8 \pm 2.4$ \\
\hline & $5 y$ & $103 \cdot 8+4 \cdot 1$ & $17 \cdot 1 \pm 2 \cdot 2$ & $55.0 \pm 2.6$ \\
\hline \multirow[t]{2}{*}{ 女 } & $3 y$ & $93.8 \pm 4.6$ & $14.2 \pm 1.9$ & $51 \cdot 2 \pm 2.2$ \\
\hline & $4 \mathrm{y}$ & $99.5 \pm 4.5$ & $15 \cdot 2 \pm 1 \cdot 6$ & $52.1 \pm 2.6$ \\
\hline 性 & $5 \mathrm{y}$ & $103.9 \pm 2.8$ & $16.4 \pm 1.5$ & $51.3 \doteq 1.4$ \\
\hline
\end{tabular}

顎角幅, 形態学顔高について表 3 に示した。

幅径に関する項目では成衰がほとんどみられなかっ た。一方, 長径, 高径に関しては成長がみられた。また すべての時期，項目で男子の方が大きな值を示した。
菌列三

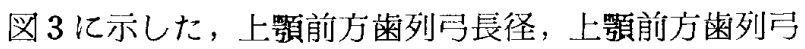
幅径，上䫑後方柪列弓長径，上顎後方歯列弓幅径，一下顎

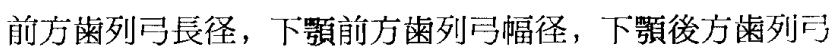
長径，下顝後方歯列弓幅径について表 4 に示した。

幅径に関する項目では顔面頭蓋と同樣に成長がほとん どみられなかった。また，長径に関しても成長量はきわ めて小さく，この時期は安定していることを示しさ。

\section{体格の指数}

奵児期の栄養発命状態を表現するRohrer Indexにつ いて表 9 に示した。この指数は増秢にしたがい減小する が, 今回の結果でもほぼ全国平均值と同様の減小を示し た.

\section{顔面頭蓋の指数}

頭長幅指数，形態学顔指数について表 5 に示した。男 女間に著明な差はなかった。

\section{米列弓の指数}

前苗列弓長幅指数, 後柬列言長幅指数を表 6 に, 上下

$$
\begin{aligned}
& \text { 頭長幅指数 }=\frac{\text { 最大頭幅 }}{\text { 最大頭長 }} \times 100 \\
& \text { 頭長幅指数 } \\
& \text { 垃頭型 X } \quad-75.9 \\
& \text { 中䫑型 } 76.0-80.9 \\
& \text { 短頭型 81.0-85.4 } \\
& \text { 過短頭型 } 85.5-X
\end{aligned}
$$

$$
\begin{aligned}
& \text { 形態学顔指数 }=\frac{\text { 形炛学顔高 }}{\text { 弓幅 }} \times 100 \\
& \text { 非態学顔指数 } \\
& \text { 過広顔型 } \mathrm{X} \quad-78.9 \\
& \text { 広 顔 型 } 79.0-83.9 \\
& \text { 中 顔 型 } 84.0-87.9 \\
& \text { 狭 顔 型 } 88.0-92.9 \\
& \text { 過狭顔型 } 93.0-X
\end{aligned}
$$

図 2 生体瞽 部 澌 項目 


\begin{tabular}{|c|c|c|c|c|c|c|}
\hline & & 最大頭長 & 最大頭幅 & 煩弓幅 & 下顎角幅 & 形態学頭高 \\
\hline 男 & $3 y$ & $155.5 \pm 8.1$ & $142.5 \pm 6.3$ & $117 \cdot 3 \pm 4.8$ & $103.8 \pm 5.6$ & $98.0 \pm 5.2$ \\
\hline \multirow[b]{2}{*}{ 性 } & $4 \mathrm{y}$ & $156.0 \pm 7.8$ & $143.1 \pm 7.2$ & $118.5 \pm 6.3$ & $105.7 \pm 6.2$ & $98.9 \pm 5.1$ \\
\hline & $5 \mathrm{y}$ & $159.8 \pm 11.3$ & $142.2 \pm 6.1$ & $118.2 \pm 3.5$ & $105.3 \pm 5.0$ & $102.1 \pm 5.3$ \\
\hline 女 & $3 y$ & $149.2 \pm 8.2$ & $139.2 \pm 5.5$ & $115.5 \pm 5.2$ & $102.7 \pm 6.9$ & $94.6 \pm 5.9$ \\
\hline \multirow[b]{2}{*}{ 性 } & $4 \mathrm{y}$ & $152.3 \pm 9.1$ & $138.3 \pm 6.1$ & $115.5 \pm 3.9$ & $102.4 \pm 5.2$ & $96.1 \pm 4.5$ \\
\hline & $5 \mathrm{y}$ & $152.3 \pm 6.5$ & $136.8 \pm 4.2$ & $113.4 \pm 4.3$ & $102.0 \doteq 5.3$ & $99.2 \pm 3.9$ \\
\hline
\end{tabular}

表 4

柬列弓長径, 歯列亏幅径 (単位: $\mathrm{mm}$ )

\begin{tabular}{|c|c|c|c|c|c|c|}
\hline & & & 前方幅径 & 前方長径 & 後方幅径 & 後方長径 \\
\hline \multirow{3}{*}{ 男 } & 上 & $3 \mathrm{y}$ & $31.5 \pm 1.7$ & $8.5 \pm 1.4$ & $47.1 \pm 2.2$ & $28.8 \pm 2.0$ \\
\hline & & $4 \mathrm{y}$ & $31.7 \pm 2.1$ & $8.6 \pm 1.5$ & $47.8 \pm 2.1$ & $28.6 \pm 1.8$ \\
\hline & 顎 & $5 \mathrm{y}$ & $32.0 \pm 1.8$ & $9.1 \pm 1.2$ & $46.8 \pm 2.0$ & $29.3 \pm 1.6$ \\
\hline \multirow{3}{*}{ 性 } & 下 & $3 \mathrm{y}$ & $24.7 \pm 1.9$ & $4.9 \pm 1.2$ & $38.6 \pm 1.2$ & $25.5 \pm 2.3$ \\
\hline & & $4 \mathrm{y}$ & $24.6 \pm 1.7$ & $5.2 \pm 1.3$ & $40.2 \pm 1.6$ & $25.7 \pm 1.8$ \\
\hline & 頡 & $5 \mathrm{y}$ & $25.0 \pm 2.1$ & $6.0 \pm 1.2$ & $40.0 \pm 1.3$ & $26.5 \pm 1.6$ \\
\hline \multirow{3}{*}{ 女 } & 上 & $3 \mathrm{y}$ & $30.7 \pm 1.6$ & $8.3 \pm 0.9$ & $45.2 \pm 1.5$ & $28.5 \pm 1.4$ \\
\hline & & $4 \mathrm{y}$ & $30.9 \pm 1.5$ & $8.3 \pm 1.5$ & $46.0 \pm 2.0$ & $28.2 \pm 1.7$ \\
\hline & 顎 & $5 \mathrm{y}$ & $31.1 \pm 1.5$ & $9.2 \pm 1.6$ & $44.8 \pm 2.3$ & $29.3 \pm 0.7$ \\
\hline \multirow{3}{*}{ 性 } & 下 & $3 y$ & $24.3 \pm 1.1$ & $4.7 \pm 1.2$ & $38.4 \pm 1.3$ & $25.3 \doteq 1.7$ \\
\hline & & $4 \mathrm{y}$ & $23.8 \pm 1.3$ & $5.0 \pm 1.3$ & $38.4 \pm 1.4$ & $25.2 \pm 1.8$ \\
\hline & 領 & $5 \mathrm{y}$ & $23.6 \pm 1.6$ & $6.0 \pm 1.4$ & $38.7 \pm 1.7$ & $25.8 \pm 2.7$ \\
\hline
\end{tabular}

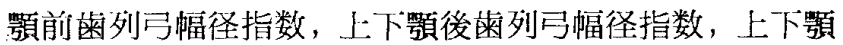
前宩列弓長径指数，上下顎後菌列弓長径指数を表 7 亿示 した.

表 6 では各項目とも次第に指数は娍小していく倬向を

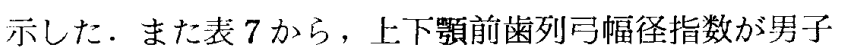
で変化が小さく，女子では僅かに増大したことを除き， いずれの指数も次第に減小した。

\section{顔面頭蓋と歯列弓の指数}

上頱では煩弓幅前歯列弓幅径指数, 煩弓幅後蒾列弓幅 径指数, 下頡では下顎角幅前歯列弓幅径指数, 下顎角幅 後米列弓幅径指数について, 表 8 に示した.
表 5 頭長幅指数, 形態学顔指数

\begin{tabular}{l|l|ll}
\hline \multicolumn{2}{c|}{} & 頭長幅指数 & 形態学顔指数 \\
\hline & $3 \mathrm{y}$ & $92.0 \pm 6.6$ & $83.9 \pm 4.9$ \\
& $4 \mathrm{y}$ & $92.3 \pm 6.5$ & $83.3 \pm 4.6$ \\
性 & $5 \mathrm{y}$ & $89.3 \pm 7.8$ & $85.9 \pm 3.3$ \\
\hline 女 & $3 \mathrm{y}$ & $93.6 \pm 6.4$ & $81.9 \pm 4.5$ \\
& $4 \mathrm{y}$ & $90.8 \pm 6.0$ & $83.2 \pm 3.6$ \\
性 & $5 \mathrm{y}$ & $90.2 \pm 4.6$ & $87.4 \pm 3.6$ \\
\hline
\end{tabular}


すべての項目とも変化は小さいが，次第に減小する傾 向があった.

\section{考察}

沖縄県幼少の体格を，月略に換算した全国平均值 ${ }^{10}$ ) と比較した（表 9 )。乙れによると，身長については全 国平均よりもすべての時期で小さい值を示し，体重は 4,5 歳之も全国平均を下回った。幼児期の栄養発青状 態を表現する Rohrer Index（体重/身長 ${ }^{3} \times 100$ ）比 較すると ${ }^{111}$ 著明な差はなかったことから，沖縄県男女

\section{表6 歯列序無幅指数}

\begin{tabular}{|c|c|c|c|c|}
\hline & & & 前歯列户长幅指数 & 後歯列宁長幅指数 \\
\hline & 上 & $3 y$ & $373.9 \pm 37.2$ & $163.9 \pm 10.5$ \\
\hline 男 & & $4 \mathrm{y}$ & $365.9 \pm 50.8$ & $167.8 \pm 10.7$ \\
\hline & & $5 \mathrm{y}$ & $356.4 \pm 40.9$ & $159.8 \pm 8.8$ \\
\hline 性 & 下 & $3 \mathrm{y}$ & $528.8 \pm 85.5$ & $155.5 \pm 12.8$ \\
\hline & & $4 \mathrm{y}$ & $471.7 \pm 101.7$ & $157.1 \pm 10.2$ \\
\hline & 强 & $5 \mathrm{y}$ & $412.4 \pm 55.7$ & $148.6 \pm 9.5$ \\
\hline & 上 & $3 y$ & $372.7 \pm 29.5$ & $159.9 \longleftarrow 4.7$ \\
\hline 女。 & & $4 \mathrm{y}$ & $385.0 \pm 69.7$ & $163.5 \pm 11.9$ \\
\hline & 㜏 & $5 \mathrm{y}$ & $342.8 \pm 65.2$ & $156.7 \pm 14.9$ \\
\hline 性 & 下 & $3 y$ & $544.5 \pm 134.6$ & $152.4 \pm 10.1$ \\
\hline & & $4 \mathrm{y}$ & $502.4 \pm 141.6$ & $153.3 \pm 10.2$ \\
\hline & 㜏 & $5 \mathrm{y}$ & $414.2 \doteqdot 113.7$ & $152.4 \pm 17.2$ \\
\hline
\end{tabular}

表 7
幼児は身言，体重のバランスはほほ平均的であると思わ れるが（表 9）身長は低く，体重はやや軽い傾向がある ようである，成長発育について検討する場合，成長途中 のある時期に大きい，小さいというととから優少を結論 づけることは危険である，成長の仕方はそのピークの時 期, 個人差, 遺伝など多くの要因があるからである。し かし，体格の都道府県別の地域差 ${ }^{21}$ より，11歳男女の

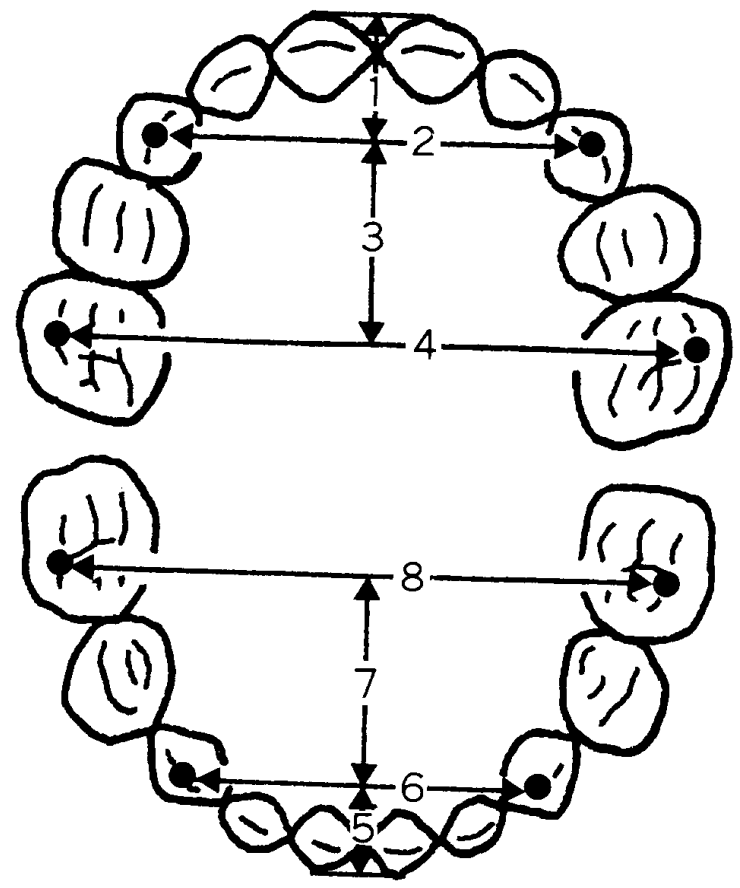

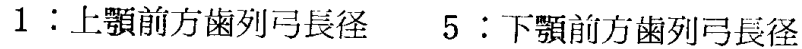
2 : 上顎前方雬列弓幅径 6 : 一顎前方歯列弓幅径

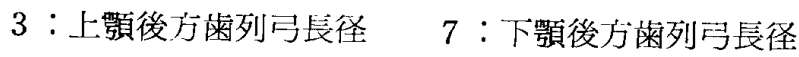

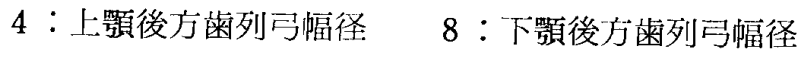

図 3 歯列弓計测点および涪测項目

\begin{tabular}{|c|c|c|c|c|c|}
\hline & & 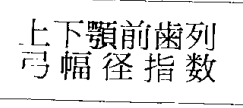 & 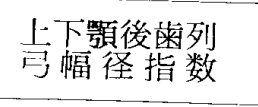 & 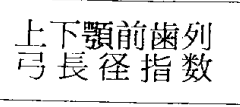 & $\begin{array}{l}\text { 上下颚後曾列 } \\
\text { 等長径 指数 }\end{array}$ \\
\hline 奛 & $3 \mathrm{y}$ & $128 \cdot 0 \pm 6 \cdot 3$ & $173.2 \pm 24.5$ & $120.1 \pm 2.4$ & $115.0 \pm 3.8$ \\
\hline \multirow[b]{2}{*}{ 性 } & $4 \mathrm{y}$ & $129.0 \pm 6.3$ & $167.7 \pm 26.5$ & $118.8 \pm 3.3$ & $111.5 \pm 4.8$ \\
\hline & $5 \mathrm{y}$ & $128.8 \pm 4.9$ & $156.1 \pm 18.3$ & $112.7 \pm 2.4$ & $106.2 \pm 2.3$ \\
\hline 女 & $3 \mathrm{y}$ & $127.6 \pm 4.0$ & $184.6 \pm 33.1$ & $118.6 \pm 2.7$ & $113.1 \pm 4.6$ \\
\hline \multirow{2}{*}{ 性 } & $4 \mathrm{y}$ & $129.9 \pm 5.5$ & $172.3 \pm 35.8$ & $119.1 \pm 2.9$ & $112.4 \pm 5.1$ \\
\hline & $5 \mathrm{y}$ & $131.3 \pm 7.5$ & $148.5 \pm 32.4$ & $115.9 \pm 3.9$ & $111.8 \pm 5.4$ \\
\hline
\end{tabular}


身長で油縄県男女はともに全国平均値を大きく下回り， 男子は最小，女子は最小から 2 番目の值であった。また 宮崎ら ${ }^{13}$ ' は沖縄県中・高校生の体格について 全国平均 を下回ると報毕している，以上のことから，沖縄県男女 は幼児期から思春期まで身長が低い傾后があるようであ る。

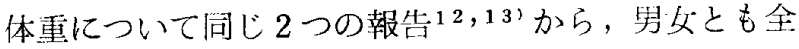
国平均值を下回っているが，ともに身長ほど著明ではな かった。

顔面頭蓋の計測は学童についての報告が多く ${ }^{14-171 ，}$ 低年柃を対象としたものは日本では僅かに東京都立大身 体適性学研究室が頭長, 頭幅を報告している ${ }^{18)}$ 。今回 の計測值と比較すると，最大頭長は男女とも沖縄県の方 が約 $5 \sim 9 \mathrm{~mm}$ 小さく, 最大頭幅では 3 歳時男女とも沖 縄県の方が $1.8 \mathrm{~mm}$ 大きいが，5歳時には逆に男子で 1.6 $\mathrm{mm}$ ，女子で $3.0 \mathrm{~mm}$ 小さい值を示した。

生体計測での煩马幅, 下顎角幅, 形態学顔高など 媣
さ，高さ汇関する項目では男女とも僅かながら增大があ ったが，幅径に関する項目ではほとんど変化がなかっ た。

従って表 5 に示したように，頭長幅指数はやや減少傾 问にあり, 形態学顔指数はやや増大する傾向があったて とは当然の結卧といえる.Scammonら ${ }^{19}$ は頭蓋の成 长は 5 歳の時点で成人に対して $15 \%$ の成長の potential があると報告している，Hellmanら ${ }^{20}$ は脳頭蓋の大き さは 2 歳で成人の $73 \% ， 6$ 歳で $93 \%$, 顔の深さ,すなわ ち最大頭長に関連する成長方向は 2 歳で $77 \% ， 6$ 歳で 82 \%の成長達成度を示すと報告している，以上のてとか ら, 頭長よりも頭幅の方が早く成長達成するため, 成人 に比へてて幼児では短頭傾问が強い之考えられる。

また小浜 ${ }^{21}$ 'は日本人の頭長幅指数は約 $77 \sim 85$ で, 中 ・短頭型であると報告している，乙の数值は成人につい てのものであり，計測值自体が幼児とは異なっている。 最大頭長が成人に対し， 5 歳の時点で男子 $83 \sim 89 \%$, 女 表 8 顔面頭蓋 - 荬列 巨J の 指 数

\begin{tabular}{|c|c|c|c|c|c|}
\hline & & $\begin{array}{l}\text { 煩弓幅前歯列 } \\
\text { 幅 径 数 }\end{array}$ & $\begin{array}{l}\text { 煩湢後歯列 } \\
\text { 幅径数 }\end{array}$ & $\begin{array}{l}\text { 下䫑角幅前菌列 } \\
\text { 数 佳 }\end{array}$ & $\begin{array}{l}\text { 下䅡角幅後歯列 } \\
\text { 幅 佳 指 }\end{array}$ \\
\hline \multirow[t]{2}{*}{ 是 } & $3 y$ & $27.4 \pm 0.5$ & $41.5 \pm 1.7$ & $24.0 \pm 1.8$ & $39.2 \pm 1.9$ \\
\hline & $4 \mathrm{y}$ & $26.5 \pm 2.2$ & $41.2 \pm 2.8$ & $23.3 \pm 1.9$ & $38.5 \pm 2.0$ \\
\hline 性: & $5 \mathrm{y}$ & $27.1 \pm 1.5$ & $39.6 \pm 1.8$ & $23.7 \pm 2.0$ & $37.0 \pm 2.6$ \\
\hline \multirow[t]{2}{*}{ 女 } & $3 y$ & $26.7 \pm 1.6$ & $40.0 \pm 2.3$ & $24.2 \pm 0.4$ & $38.7 \pm 1.8$ \\
\hline & $4 \mathrm{y}$ & $27.3 \pm 1.3$ & $40.1 \div 2.1$ & $23.8 \pm 1.8$ & $38.0 \pm 2.1$ \\
\hline 性 & $5 \mathrm{y}$ & $26.8 \pm 1.3$ & $38.9 \pm 2.4$ & $22.2 \pm 1.8$ & $36.9 \pm 2.7$ \\
\hline
\end{tabular}

表 9

Rohrer Index, 体格の沖縄県・全国平均值の比較

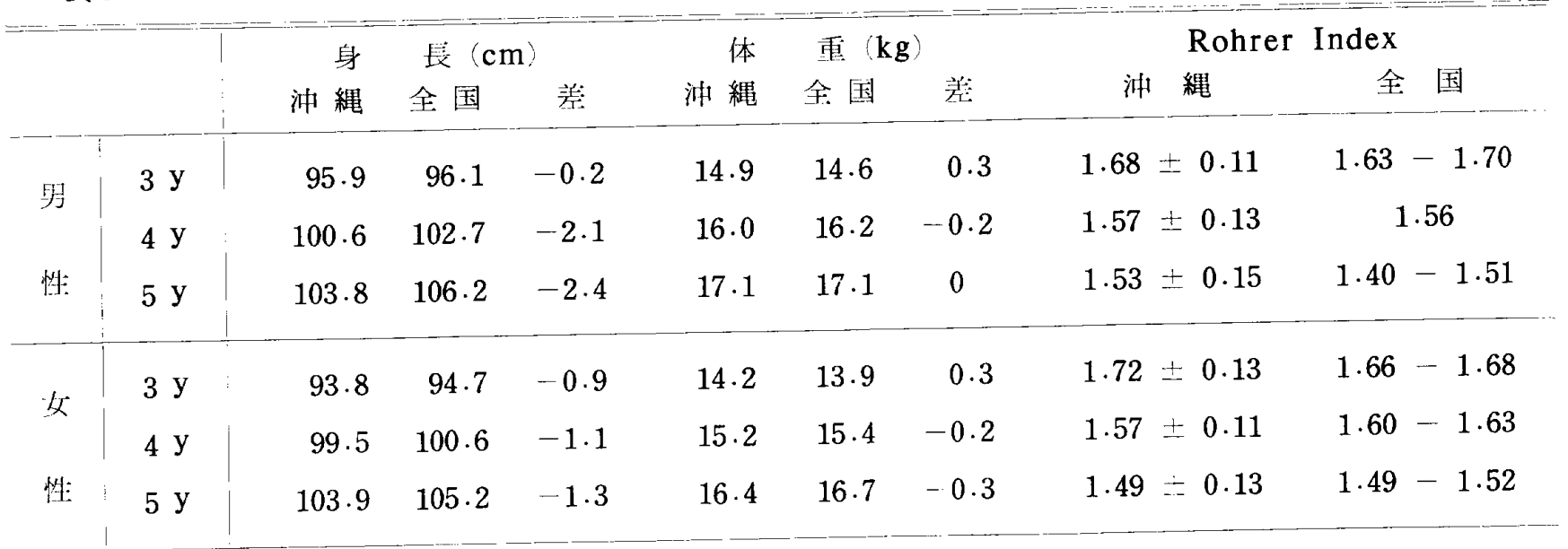


子 80 ～ $86 \%$ の成長達成度であり，10〜20\%の成言の potential を残すと推察される.

一方, 最大頭幅について 5 歳以後に $3 \sim 12 \%$ の成長の potential を残すだけで, 頭部幅径の成長達成度が長栙 に比へて早期に進行するととを示しており, Hellman $ら^{20}$ の報告と一致した。 今回の計測結果から幼児期は 過短頭型であるが，その後の成長に伴い，次第に中・短 頭型に変化すると推察される.

形態顔指数は表 5 亿示す通りであるが，原田ら ${ }^{22}$ は

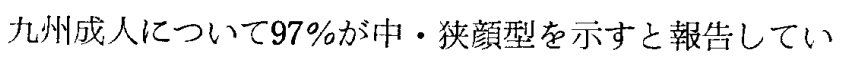
る. 顔面成長について, Krogmanら ${ }^{23}$ は垂直的な成 長よりも幅径の成長達成度の方が早いと報告している。 生後中・下顔面の垂直成長は十分認められることから, 幼児期は広・中顔型であるが，今後の成長に伴い，次第 に中・狭顔型に変化すると推察される。

歯列弓と顔面頭蓋について報告例はあるが，それらは ほとんどが，石高模型やX線規格写真計測で14-17，24一 26), dental age II A の時期に歯列弓と生体計測を対 応させて報告した例は見当らなかった．

霜列弓と顔面頭蓋との関連については表 8 亿示したよ うに4 指数である.乙れらの指数は資料不備のものを除 いたため, 各計測項目の平均値と多少異なる点があり, そのため各々の内容について再検討した，上頍に関する 煩弓幅前歯列弓幅径は男女とも各時期安定しており，煩 弓幅後歯列弓幅径指数は次第に僅かに減小する傾向を示 した.てれは指数の分母である煩弓幅が备時期安定して いたのに対し, 分子である後菊列弓幅径が男女とも僅か
に娍小したととが原因と考えられる，下顎に関する下顎 角幅前歯列弓幅径指数は男子は各時期安定していたが， 女子は次第に僅かながら減小する傾向を示し，下顎角幅 後歯列弓幅径指数は男女之も次第に減小寸る傾向を示し た。これらは分母である下顎角幅の安定と，歯列引幅が 僅かに減小したことが原因と考元られる。

\section{要 約}

1. 乳歯列弓の形態学的変化と顔面頭蓋および体格の 変化々の関連性を調查するために, 沖縄県那䩶市の保育 園の歯牙年齢 $11 \mathrm{~A}$ の男子156名, 女子107名, 計263名の身 長など 8 項目について計測した。

2. 沖縄県幼坚は全国平均值に比べて，身長は男女と も小さく，体重は著明な差がなかった。

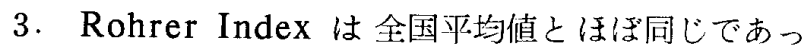
た.

4. 顔面頭蓋の形態は男女とも, 過短頭型, 広・中顔 型を示した。

5. 歯列弓と顔面頭蓋の関係で，上下顎とも骨格系は 比較的安定していたのに比心，歯列弓幅径は，増粭とと もに僅かに減少する傾向を示した。

稿を終わるにあたり，終始御指導ならびに御校閲を賜 った佐伯榮一教授に刘し厚く感謝申し上げます，また， 今回の資料の調查に御協力頂いた，宇栄原第 2 保育園， 久場川保育園, 樋川保育園, 泊保育園, 小禄保育園, 与 儀保育園の関係各位に感謝の意を表します。

\section{引用文献}

1) 岩沢忠正：健全乳㐘の交換時期順序上不正咬合発生の関係について, 第 2 編 日矯歯誌 $19: 1-21,1960$.

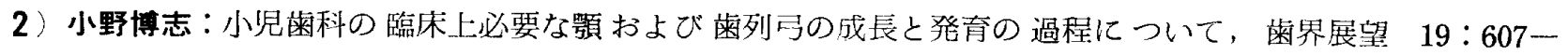
626,1962 .

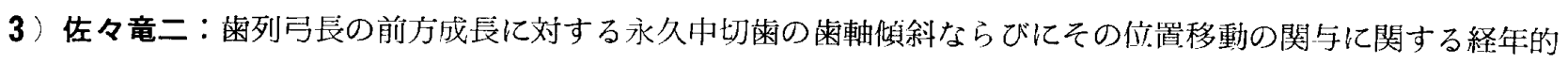
研究, 口病誌 $38: 519-532,1971$.

4 ) 岡部浩子：永久歯萌出の場の研究, 雬学 $64: 688-707,1976$.

5 ) 山浦 雪: 永久宩列弓の発青に関する研究, 大日本歯科医学会雑誌 $3: 97-110,1960$.

6 ) 熊沢正敏：身長発育と歯列幅径および長径発育との関連に関する計測学的研究, 第IV編歯科学報 68 : $1671-1683,1968$.

7） 6 ) より引用. 森 正也：歯牙の萌出曲線について, 日蒾会誌 $13(7)$ 別刷, 1960 .

8 ) 鈴木 尚：人体計測, 第 1 版, 人閒と技術社, 東京, 1973, 15-101.

9) 水岛治夫: 簡約統計学, 第14版, 南江堂, 東京, 1979, 41-43.

10) 飯塚喜一・坪根哲郎・他：歯科衛生，第 1 版, 学建書院, 東京, 1977,42 .

11) 10)上り引用. 
12）厚生統計協会：国民衛生の動向・愿生の指標，特集 $26 （ 9 ） ： 358-363 ， 1979$.

13）宮琦秀夫・作間正則・他：昭和50年度における沖縄目中部地区, 中・高校生の身長・体重・胸囲等について (会), 九州霜会誌 $33: 185,1979$.

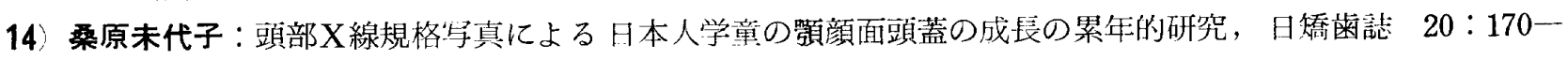
$191,1961$.

15）遠藤 孝：歯列咬合に関する狻学的研究，日矯歯誌 $29: 111-126 ， 1970$.

16）一色泰成・山口秀晴・他：小学校 6 年間連続 Simon 氏顎態模型に上る研究, 歯科学報 $70: 220$ - 243, 1970 .

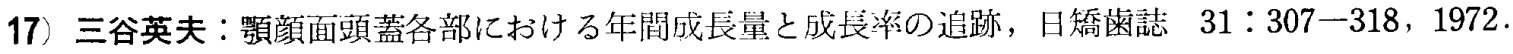

18）馬場一雄・寺脇保・他：小児の正常值, 第 1 版, 医学書院, 東京, 1979,13 .

19）Graber，T．M. ·中後忠男・他訳：米科矯正学，第 3 版，医茵薬出版，東京，1976，60-62.

20）上り污用.

21) 藤田恒太郎・寺田春水：生体観察，第12版，南山堂，東京，1978，239.

22）上條雍彦：口腔解剖学, 第 1 巻, 第 6 版, アナトーム社, 東京, $1975,268-273$.

23) Krogman, W. M. : Facing facts of face growth, Amer. J. Orthod. and Oral Surgery 25 : $724-731,1939$.

24)坂本敏彦：日本人顔面頭蓋の成長に関する研究，日矯歯誌 $18: 1-17,1959$.

25）坂井正彦：経年石膏模型に上る後方永久歯萌出の場の研究，歯学 $61: 1120-1139,1974$.

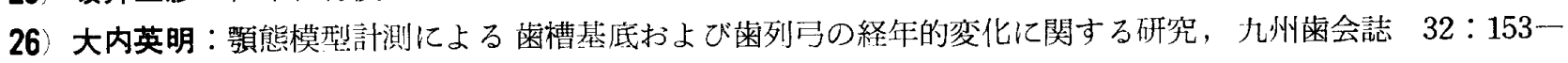
$176,1978$. 